\title{
Slovak Language
}

National Cancer Institute

\section{Source}

National Cancer Institute. Slovak Language. NCI Thesaurus. Code C154116.

An Indo-European West Slavic language that is the official language of Slovakia. 